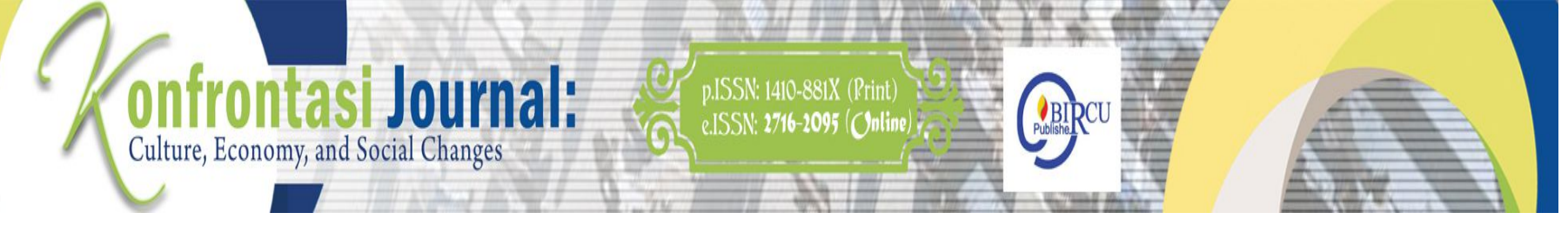

\title{
Public Service Satisfaction Licensing in Deli Serdang Regency
}

\section{Nufaris Elisa}

Universitas Amir Hamzah, Medan, Indonesia

\section{Abstract}

This study aims to determine the satisfaction of public service in the field of licensing Deli Serdang regency. Location of the research conducted in the area of Deli Serdang regency government is the reason for this is a site selection study for Deli Serdang regency. This study uses secondary data sources as the primary data source, which is equipped with a primary data source as a supporter. Sources of data mainly obtained from the Department of Commerce Office of P2KPM and Deli Serdang regency. The results showed that people's satisfaction of public services in Deli Serdang regency values obtained cumulative index of 21.7 in the range of 17-23 (moderate), so it can be concluded that the implementation of public service in Deli Serdang Regency included in the rate being.
Keywords

satisfaction; public service; licensing

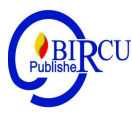

\section{Introduction}

The principle of decentralization in the implementation of autonomy is to give flexibility to the organs of the autonomous region which have the right to manage their own households in the context of decentralization. In the principle of decentralization, there is a complete handover of authority from the central government to regional governments regarding certain functions, so that regional governments can take full initiatives, whether related to policy, planning, implementation, or financing. The regional government carries out the administrative affairs delegated so that it becomes its own household affairs. Decentralization as a political and institutional tool is expected to strengthen the mandate of county governments in watershed governance and facilitate the involvement of stakeholders at different levels in the food sector. However, it has often been easier for the central government to decentralize powers to the county governments than to ensure that the county governments have the needed resources, capabilities and accountability necessary for watershed management (Naburi et al, 2020).

The reconstruction of the relationship between central and regional government in Indonesia has undergone significant changes after the implementation of regional autonomy. The decentralization instrument also changed the management of local resources as a form of delegation of authority from the center to autonomous regions to be more independent. Supporting services for business activities such as business permits, legal certainties, and a conducive business climate, also play a less fragmented role in the central government alone. The local government is now expected to become a local actor in creating a licensing system that supports business activity mechanisms and regional resource management for the benefit of local communities.

The decentralization policy embodied in Law Number 22 Year 1999 concerning Regional Government and Law Number 25 Year 1999 concerning Central and Regional Financial Balance has been implemented in the public administration system at the Central, Provincial and Regency / City levels. The implementation of this public policy during the 
period 2001 - 2004 has been re-evaluated and the two laws were later revised with the new Regional Autonomy Law, namely Number 32 of 2004 concerning Regional Government and Law Number 33 of 2004 concerning Central Financial Balance and Area. Seeing the substance of the new law, it appears that there are changes and improvisations so that it will automatically bring about changes in the stages of public policy implementation in the implementation of regional autonomy.

Public understanding of the legal basis or established public policies is one of the important factors to ensure quality public service standards. Public understanding of the formulation of public policies that regulate procedures and mechanisms for providing public services can be measured from the ease with which people understand these procedures, the readiness of the bureaucracy to provide clarity to the public, transparent information about the intended public service standards and the behavior of public service officers towards society in practice provision of public services. The policy formulation is of course at the stage of implementing public policies that have been previously determined.

One of the crucial public service areas is the issue of licensing. Licensing is an aspect of regulation and legality of various fields of community activity which is determined by state administrative officials through certain procedures. Licensing issues involve two sides of interest, namely, the interest of the regional government to regulate certain activities carried out by the community so that it is in accordance with the planning, conditions and needs of the local government, on the other hand, is the interest of the community's need to obtain legal certainty in conducting business and activities that have effects in the social, economic, political and so on.

Development activities and investment in the regions are closely related to granting permits to parties who need them. The Regional Government, of which the DPRD is one of the elements, has the authority to determine the conditions that must be met by a licensing applicant in order to obtain a license he needs. The stipulation of these conditions is of course intended to achieve the goals that the Regional Government wants to achieve, which is realized in the form of a Regional Regulation.

All problems that arise in licensing services become increasingly crucial when the procedures for granting Licensing are not standardized comprehensively and are not stipulated in a good service standard. Licensing services will not give satisfaction to the community if the implementation is not coordinated and runs independently in their respective sectors. One of the implementation of Law Number 32 of 2004 concerning Regional Government in the future is how to improve the quality of public services in accordance with the general principles of state administration and at the same time embody the main principles of decentralization policy, namely democratization, public accountability and community empowerment.

Licensing is required by individuals and groups of business actors as legality, both in the form of licenses and business registration certificates (TDU). In this case, the organizing organization needs to socialize various information systems relating to the type of service, technical requirements, mechanisms and stages of administration, tracking the position of documents in each process, costs and completion times as well as the procedures for complaints so that the implementation of licensing services takes place effectively and efficiently (Ellyana and Ismail, 2020).

Based on the description above, the writer wants to do this research in writing a paper entitled "Public Service Satisfaction in the Licensing Sector in Deli Serdang Regency" 


\section{Review of Literatures}

The theoretical framework in legal research is very necessary to make the types of values by legal postulates to the highest philosophical basis. The theory of law itself can be called a continuation of studying positive law, at least in such an order that we clearly reconstruct the existence of legal theory.

Based on the foregoing, the theoretical framework for a study has several uses as follows:

1. This theory is useful for refining or specifying the facts to be investigated or tested for truth.

2. Theory is very useful in developing a system of classification of facts, building a structure of concepts and developing definitions.

3. The theory is usually a summary of the things that are already known and the truth is tested regarding the object under study.

4. Theory provides the possibility of predicting future facts, because it is known the reasons for the occurrence of these facts and perhaps these factors will arise again in the future.

Indonesia is a state based on law as reflected in the 1945 Constitution, in a constitutional state, state power is exercised according to the basic principles of justice so that it is constitutionally bound to the constitution. The law becomes the limit, determinant, the basis for the ways and actions of the government and all agencies in interfering with the rights and freedoms of citizens. On the basis of law also the rule of law organizes what is the goal of the state. So it doesn't make sense for a rule of law to be created in a way that is against the law.

Moh. Kusnardi and Hermaily Ibrahim in their book entitled "Introduction to Indonesian Constitutional Law" states that the elements of a rule of law can be seen in the rule of law in a narrow or formal sense. In a narrow sense, only 2 (two) important elements are known in a rule of law, namely:

1. Protection of human rights.

2. Separation / distribution of power.

Meanwhile, the rule of law in the formal sense has more elements, including, among others:

1. Protection of human rights.

2. Division / separation of powers.

3. Every government action must be based on laws and regulations.

4. There is an independent administrative court.

Based on the description of the concept of the rule of law, there are 2 (two) basic substances, namely:

1. There is a constitutional understanding.

2. Democratic system or people's sovereignty.

The understanding of the constitution means that government is based on basic law (constitution), not based on mere power (absolutism). The logical consequence of the acceptance of constitutional understanding or governance based on the constitution (wetmatigheid van bestuur), means that the governmental power of the president's state as the executive holds governmental power according to the constitution, the president has the right to advance laws to the people's representative institutions, the president establishes a regulation Government to enforce laws. With this principle the president also issues regulations.

Constitutionalism requires the existence of 2 (two) important elements at once; first, law which becomes a barrier to the possibility of arbitrary power. And second, full political 
accountability from the government to the governed. Through this constitutional system in government, it will give birth to equal rights and obligations of citizens as well as protection in law and government, because the government (ruler) in implementing rules refers to the applicable basic rules (constitution) not the power they have.

The Government of the State as the integrity of the power of the masses must continue to adapt to the changes and development of society or its social system so that it can maintain a balance between its role or implementation of its function and the objectives to be achieved. In an effort to achieve this, it is not necessary for the king to be in harmony with the goals desired by social groups and economic groups in the state, but also creativity to create directionally the various conditions of social welfare desired by society.

As a consequence of the inherent function of public services, state administration is required to accept positive responsibility in terms of creating and distributing levels of income and wealth and providing public welfare programs. If this positive responsibility can be carried out, the existence of the government will grow into a big and strong government, both within the scope of functions and the number of personnel required carrying out its duties and responsibilities.

The development of the role and function of the state administration has an impact on the occurrence of at least two important problems, namely, "First, with the rapid increase in the number of personnel administering public service functions, it is assumed that there will be an increase in the number of victims as a result of pressure from the government regime. The relationship between such assumptions may be reflected in the tendency of increasing fraud and actions that harm the people in achieving or realizing people's welfare. Second, there is a more crucial issue, namely the possibility of concentration of power in state administration. This possibility is more open to the granting of a "freedom" to act on Ermussen's own initiative; pauvoir discretionare) in order to solve the problems that are being faced and need to be resolved immediately.

To avoid the negative impact of the development of the roles and functions of the state administration, the concept of a modern rule of law is a must, as stated by FJ. Stahl in his conception of the rule of law namely: The state must become a rule of law, that is the watchword and in fact also becomes the driving force for development in this new era. The state must determine carefully the paths and boundaries of its activities as well as the environment (atmosphere) of citizens' freedom according to the law and must guarantee that atmosphere of freedom is impenetrable. The state must realize or impose moral ideas from the state's point of view, also directly no further than it should be according to the legal atmosphere.

This concept is very relevant the concept of the welfare state where the definition of a modern rule of law is not only to maintain security but to actively participate in social affairs for the welfare of the people. The Indonesian state is clearly a country that applies the concept of the welfare state, as stated in the preamble of the 1945 Constitution in the fourth paragraph which is used as the basis for national development carried out in order to realize national goals, namely: Then rather than that to form the Indonesian state government that protects the entire Indonesian nation and all the blood of Indonesia and to promote the welfare of the Imam, educate the life of the nation and participate in implementing world order based on independence, eternal peace and social justice.

a) The concept of a welfare state as stated in the preamble of the fourth paragraph of the 1945 Constitution is reinforced by the statement in Article I paragraph (3) of the 1945 Constitution resulting from the fourth amendment of 2002 that the state of Indonesia is a rule of law. The logical consequences that must be faced as a legal state and a welfare state according to Sjachran Basah, in finding which legal options should be used in people's 
lives, especially in Indonesia, then the conditio sine qua non-law must have multiple functions:

b) Directive, namely as a guide in development to shape the society to be achieved in accordance with the goals of state life.

c) Integrative, namely as a builder of national unity.

d) Stabilitative, namely as a caretaker (including the results of development) and guardian of harmony, harmony, balance in the life of the state and society.

e) Perfect, namely as a complement to the actions of the state administration and the attitudes of citizens in the life of the state and society.

f) Corrective, namely against citizens and state administrations in getting justice.

In line with these five legal functions, the law must be able to answer problems that arise as a result of fundamental changes in society, especially in the era of globalization or the era of free trade at this time through the process of industrialization and transformation in the field of information technology. Economic development that will bring change and progress in civilization and the welfare of society needs to be followed by development in the field of law as a determinant factor.

As stated by Mochtar Kusumaatmadja, "law is a means of reforming society".17Based on an assumption that law does not only aim to achieve order and justice, but can also function as a means to change or renew society. The law as mentioned above, can be approached from the basic functions which can be performed by law in society which shows that the law obtains an appropriate function in the division of tasks in the entire social structure. According to EA Goebel, in society, law has a function:

a. Establishing a pattern of relationships among community members by showing which types of behavior are allowed and which are prohibited;

b. Determine the allocation of powers detailing who is allowed to enforce coercion, who must comply with it, who will choose the appropriate and effective sanctions;

c. Resolving disputes;

d. Maintaining the ability of society to adapt to changing conditions of life, that is, by reformulating the essential relationships between members of society.

In this regard, Achmad Ali argues that:

1. The function of law as a means of social control can be carried out by a centralized power which is currently in the form of state power exercised by "the ruling class" or an "elite". The law usually takes the form of written law or legislation.

2. The function of law as a means of social control can also be carried out "from below" by the community itself. The law is usually in the form of unwritten or power law.

According to Achmad Ali, the implementation of the legal function as a means of social control is determined by two things, namely:

1. The rule of law factor itself;

2. The implementing factor (the person) is legal.

Several legal functions in social change and in people's lives as described above are associated with the implementation of decentralization and regional autonomy policies in response to demands for change in society with the enactment of the Regional Autonomy Law, namely Law Number 22 Year 1999 and Law Number 25 of 1999 and then the following five years were enhanced by the enactment of Law Number 32 of 2004 and Law Number 33 of 2004, requiring the emergence of a new paradigm in determining public policies in the context of development and implementation of regional government in accordance with the powers that have been given in the context of regional autonomy.

The application of regional autonomy based on Law Number 32 Year 2004 remains with the principle of broad, real and responsible autonomy. The purpose of broad autonomy 
is that regions have the duties, powers, rights and obligations to handle government affairs that are not handled freely by the central government to provide services to regional communities. Real autonomy means handling governmental affairs that actually already exist in accordance with the potential and characteristics of each region. Responsible autonomy means that the implementation of autonomy must be in line with the objectives of providing autonomy, namely regional empowerment and improvement of people's welfare.

Regional autonomy in Law Number 32 of 2004 is more oriented towards local communities (more populist in nature) than to regional governments, meaning that the autonomous region's authority to regulate and manage the interests of local communities is based on their own initiative based on community aspirations. The authority of the regional government is only as a tool and facilitator to provide services to the community, channel the aspirations and interests of the people, and provide facilities to the people through supervision and community empowerment.

Regional autonomy gives as broadly as possible to the regions to regulate and manage regional households themselves, the authority of the autonomous regions to regulate and manage the interests of the local community according to their own initiatives based on community aspirations in accordance with statutory regulations. The principle of implementing regional autonomy is to give flexibility to regions to determine their own way of life, which is practically in all matters, permits and the like that can now be resolved in the regions.

Autonomy is not simply the transfer of power to the regions, but regions have the authority, the freedom to make decisions, to govern themselves. Authority to regulate itself is essential for regional progress. For this reason, local governments must formulate regional regulations to provide the best service to the people of their regions

As a source of law in the order of laws and regulations, Perda is one of the means in implementing regional autonomy.25Perda is a legal product made by DPRD together with local governments. The initiative of a Perda can come from the DPRD or from the regional government. The Perda is basically a further elaboration of higher-level laws and regulations, taking into account the characteristics of each region. The authority to make regional regulations is a concrete manifestation of the implementation of autonomy rights that a region has, with the aim of realizing regional independence and empowering the community. To implement a perda, the regional head determines regional head regulations and / or regional head decrees. A perda will function effectively if it is supported by law enforcement efforts against it.

Perda is a regional policy made to implement regional autonomy. This regional policy must not conflict with higher laws and regulations and the public interest and other regional regulations. Law Number 32 of 2004 creates a political context that provides an opportunity for the creation of a balanced political institution between the regional government and the DPRD in shaping decisive public policies. 3 In this context, the implementation of regional autonomy must be based on the principles that lead to increased supervision and function of the DPRD, both in the legislative, supervisory and budgetary functions.

Based on Article 12 of Law Number 10 of 2004 concerning the Formation of Legislative Regulations, the content of the perda is all material content in the administration of regional autonomy and co-administration, and accommodates the special conditions of the region and the further elaboration of higher laws and regulations. Based on Law Number 34 of 2000 concerning Amendments to Law Number 18 of 1997 concerning Regional Taxes and Regional Levies (hereinafter abbreviated as Law No.34 of 2000), regional regulations can regulate various types of taxes and levies that have been transferred to the regions. 
Specifically for public services in the field of licensing, the Deli Serdang Regional Government is still in the stage of making systematic efforts to find the right public policy formulation so that the implementation of public services in the licensing sector can achieve a level of community satisfaction in accordance with the developments and progress that has been achieved by the Deli Serdang community. . Public services in the licensing sector carried out by the Deli Serdang Regional Government in the implementation of regional autonomy have so far not been in accordance with the spirit of democratization and decentralization which requires the importance of public participation, transparency and public accountability in service delivery.

In line with advances in information technology, the implementation of public services must be supported by a system and work mechanism as well as adequate institutional capacity and human resources so that prime services can be created with standard service standards in the delivery of public services.

\section{Research Methods}

In accordance with the characteristics of the formulation of the problem in this study, this type of research is classified as a normative juridical research which is descriptive analysis by referring to the legal norms that apply in regional government. What is meant by juridical normative is to approach legal norms in analyzing existing problems. This research is a doctrinal research (doctrinal research), namely research that analyzes law, whether written in a book (law in written in book) or law decided by a judge through a judicial process (law as it is decided by the judge through judicial process).

It is intended to be descriptive analytical because this research is not only aimed at describing the symptoms or legal phenomena related to the application of the licensing system in Deli Serdang regency but is also aimed at analyzing these legal phenomena. So, this research does not directly aim to build or test hypotheses or theories, but instead seeks to describe and explain the performance of the Deli Serdang Regency Government in implementing the permit system in the Deli Serdang area and the obstacles and solutions faced by the Deli Serdang regional government attack.

\section{Discussion}

\subsection{Determination of Public Service Standards}

In Indonesia, efforts to establish public service standards in the framework of improving the quality of public services have actually been carried out for a long time. These efforts were shown, among others, by the issuance of various policies such as:

1. Inpres No. 5 of 1984 concerning Guidelines for Simplification and Control of Licensing in the Business Sector,

2. Decree of the Minister for Administrative Reform No. 81 of 1993 concerning Guidelines for Public Service Management.

3. Inpres No. 1 of 1995 concerning Repair and Improvement of the Quality of Government Apparatus Services to the Community.

4. Coordinating Minister for Wasbangpan Circular No. 56 / Wasbangpan / 6/98 concerning Real Steps to Improve Community Services. Minister of Home Affairs Instruction No. 20/1996;

5. Menkowasbangpan Circular No. 56 / MK. Wasbangpan / 6/98; Menkowasbangpan Letter No. 145 / MK. Waspan / 3/1999; to Minister of Home Affairs Circular No. 503/125 / PUOD / 1999, all of which lead to improving the quality of service. 
6. Kep. Menpan No. 81/1993 concerning Guidelines for Public Service Management

7. Ministry of Home Affairs Circular No. 100/757 / OTDA regarding the Implementation of Mandatory Authority and Minimum Service Standards, in 2002.

8. Kep. Menpan No: 63 / KEP / M.PAN / 7/2003 concerning General Guidelines for the Implementation of Public Services.

However, so far the public service standards as referred to are still mostly at the conceptual level, while the implementation is still far from expectations. This is evident from the still poor quality of services provided by various government agencies as public service providers.

As for what is meant by service standard is a benchmark that is used to reference service quality assessment as a commitment or promise from the service provider to customers to provide quality service. Meanwhile, what is meant by quality service is service that is fast, pleasant, does not contain errors, and follows predetermined processes and procedures. So quality service is not only determined by the serving party, but also those who want to be satisfied or their needs met.

The benefits that can be obtained from a standard of service include:

1. Provide assurance to the public that they receive service in an accountable quality, provide a focus on service to customers, become a means of communication between customers and service providers in an effort to improve service, become a tool for measuring service performance as well as a monitoring and performance evaluation tool service.

2. Make improvements to the performance of public services. Improving the performance of public services absolutely must be done, because in state life, public services involve a very broad aspect of life. This is because the government's main task and function is to provide and facilitate various public services needed by the community, ranging from services in the form of regulations or other services in order to meet community needs in the fields of education, health, utility, social and others.

3. Improve service quality. The existence of service standards can help service provider units to be able to provide the best service for their customer communities. In this service standard, it can be seen clearly that the legal basis, service requirements, service procedures, service time, cost and complaint process, so that service officers understand what they should do in providing services. The community as service users can also know exactly what rights and obligations they must get and do to obtain a service. Service standards can also help improve transparency and accountability of the performance of a service unit.

\subsection{Public Service Satisfaction in the Licensing Sector in Deli Serdang Regency}

From the recapitulation of respondents, the following data were obtained:

Table 1. Respondent Characteristics

\begin{tabular}{|c|l|l|c|c|}
\hline No & Respondent Characteristics & Frequency (person) & Percentage (\%) \\
\hline 1 & Profession & Entrepreneur & 4 & 13.33 \\
& & Civil servants & 4 & 13.33 \\
& & entrepreneur & 19 & 63.33 \\
& & Traders & 3 & 10.00 \\
\hline 2 & \multirow{2}{*}{ Gender } & Male & 23 & 76.67 \\
& & Women & 7 & 23.33 \\
\hline 3 & \multirow{2}{*}{ Age } & <30 years & 4 & 13.33 \\
& & 30 - 40 years & 13 & 43.33 \\
& & $>40$ years & 13 & 43.33 \\
\hline
\end{tabular}


Table 1 shows that the respondents who have jobs as entrepreneurs are 4 people $(13.33 \%)$, civil servants are 4 people $(13.33 \%)$, entrepreneurs are 3 people and traders are 3 people (10\%). This shows, in general, those who take care of licensing in Deli Serdang Regency are entrepreneurs.

Table 1 also shows the gender who took care of licensing as many as 23 people $(76.67 \%)$ and 7 women (23.33\%). This shows, in general, those who take care of permits in Deli Serdang Regency are men.

Table 1 also shows that the most dominant respondents' ages were 30 - 40 years and 40 years and over, each of which amounted to 13 people $(43.33 \%)$. Respondents who are under 30 years old are only 4 people (13.33\%).

To see the implementation of public services in the field of licensing in Deli Serdang Regency, the author sees it from several aspects based on point $\mathrm{V}$ in the attachment to the Decree of the Minister of Apparatus Empowerment Number: 63 / KEP / M.PAN / 7/2003 dated July 10, 2003 regarding General Guidelines for Public Service Delivery namely the Principles of Public Service, as follows:

1. Simplicity

2. Clarity

3. Certainty of time

4. Accuracy

5. Security

6. Responsibility

7. Completeness of facilities and infrastructure

8. Ease of access

9. Discipline, politeness and friendliness

10. Comfort

Table 2. Public Service Satisfaction in Deli Serdang Regency Based on Simplicity, Clarity, Time Certainty, Accuracy, Security, Responsibility, Ease of Access, and Convenience.

\begin{tabular}{|c|l|r|r|r|c|}
\hline No. & $\begin{array}{l}\text { Elements of } \\
\text { Service }\end{array}$ & A & B & C & total \\
\hline 1 & Simplicity & 16 & 10 & 4 & 30 \\
\hline 2 & Clarity & 21 & 3 & 6 & 30 \\
\hline 3 & Certainty of time & 7 & 15 & 8 & 30 \\
\hline 4 & Accuracy & 7 & 15 & 8 & 30 \\
\hline 5 & Security & 18 & 10 & 2 & 30 \\
\hline 6 & Responsible & 14 & 14 & 2 & 30 \\
\hline 7 & $\begin{array}{l}\text { Completeness of } \\
\text { Facilities and } \\
\text { Infrastructure }\end{array}$ & 6 & 13 & 1 & 30 \\
\hline 8 & Ease of Access & 12 & 9 & 9 & 30 \\
\hline 9 & $\begin{array}{l}\text { Discipline, } \\
\text { Courtesy and } \\
\text { Kindness }\end{array}$ & 11 & 4 & 5 & 30 \\
\hline 10 & Convenience & 12 & 10 & 8 & 30 \\
\hline & \multicolumn{1}{|c|}{ total } & $\mathbf{1 2 4}$ & $\mathbf{1 0 3}$ & $\mathbf{7 3}$ & \\
\hline
\end{tabular}

Highest: $10 \times 3=30$

Lowest: $10 \times 1=10$

$30-10=20$

$20: 3=6.67$ 
Index Cumulative Criteria:

Low: 10 to 16

Medium: 17 to 23

Height: 24 to 30

Cumulative Index $=\frac{(124 \times 3)+(103 \times 2)+(73 \times 1)}{30}$

$$
\begin{aligned}
& =\frac{372+206+73}{30} \\
& =\frac{651}{30} \\
& =21.7
\end{aligned}
$$

Based on the table and calculations above, the cumulative index value of 21.7 is in the range 17-23 (moderate), so it can be concluded that the public service delivery is included in the medium level.

\section{Conclusion} namely:

From the description in this paper, conclusions can be given to answer the problem,

1. Implementation of public services in Deli Serdang Regency includes (a) implementation of technical services, including: building construction permits (IMB), billboard permits, restaurant business permits, cafes and coffee shops, transportation business permits, (b) service delivery which are general in nature, including: business place permit / $\mathrm{HO}$, trade business license (SIUP), Company Registration Certificate (TDP), Industrial Registration Certificate (TDI), Construction Service Business Permit (IUJK), heavy equipment usage permit.

2. Based on the results of a questionnaire to the community on public service satisfaction in Deli Serdang Regency obtained a cumulative index value of 21.7 in the range 17-23 (moderate), so it can be concluded that the implementation of public services in Deli Serdang Regency is included in the moderate level.

\section{References}

AG Subarsono, Public Policy Analysis, Yogyakarta, Student Library, 2008.

Ali, Achmad, Revealing the Veil of Law, Jakarta: Mount Agung, 2000.

Arif Nasution M. et al., Democratization and the Problems of Regional Autonomy, Bandung: Mandar Maju, 2005.

Arinanto, Satya, Human Rights in Political Transition in Indonesia, Jakarta: Center for Constitutional Law Studies, Faculty of Law, University of Indonesia, 2005.

Atmosudirdjo, Prajudi, State Administrative Law, Jakarta: Ghalia Indonesia, 1986.

Barata, AA The Basics of Excellent Service. Jakarta: Gramedia, 2003.

Basah, Sjachran, Legal Protection of State Administration Attitudes, Bandung: Alumni, 1992. Basah, Sjachran, Three Writings on Law, Bandung,: Armik, 1986.

Brata Kusumah, Deddy S, Dadang S, Autonomy of Local Government Administrators, Jakarta: PT. Sun, 2003. 
Budiyanto, Basics of State Administration, Jakarta: Erlangga, 2000.

Craig, S. The New Corporate Philanthrophy, Harvard Business Review, May-June, 1994. pp. 414-415

Ellyana, C and Ismail. (2020). Licensing Services in the Capital Investment Services and Integrated One Door Service (Dpmptsp) Banda Aceh City. Budapest International Research and Critics Institute-Journal (BIRCI-Journal). P. 805-815.1

HR, Ridwan, State Administrative Law, Jogyakarta: UI Press, 2002.

Hanitijo Soemitro, Ronny, Legal Issues in Society, Bandung: Alumni, 1984.

Hartono, Sunaryati, Indonesian Economic Development Law, Bandung: Bina Cipta, 1982.

Hoogerwerf, Governmental Science, Jakarta: Erlangga, 1982.

Huda, Ni'matul, Regional Autonomy, Philosophy, History of Development and Problems, Yogyakarta: Student Library, 2005.

Joko Widodo, Public Policy Analysis, Jakarta: Bayumedia, 2008.

Kaloh, Looking for Regional Autonomy Forms, a Solution in Responding to Local Needs and Global Challenges, Jakarta: Rineka Cipta, 2002.

Kiw Kian Gie, Indonesian Political Economy Analysis, Jakarta: Gramedia Pustaka Utama, 1994.

Kunarjo, Planning and Development Financing. Jakarta: UI Press, 1992.

Kusnardi, Moh. and Ibrahim, Hermaily, Introduction to Indonesian Constitutional Law, Jakarta: Center for Constitutional Law Studies, Faculty of Law, University of Indonesia, 1983.

Kusumaatmadja, Mochtar, Function and Development of Law in National Development, Bandung: Binacipta, 1970.

Lay, Cornelis, "Presidential Institutions in Indonesia", in Unlimited Study of the Indonesian Presidential Institute, Yogyakata: Pandega Media with BEM UGM, 1997.

LP3ES edited by Arselan Harahap and Maruto MD, Guidelines for Managing Licenses and Recommendations for the Industry and Trade Sector, Jakarta: Pustaka LP3ES, Jakarta, 2000 .

Madjid, Nurcholis, Islamic Tradition, Supervision and Functions in Indonesia's Development, Jakarta: Paramadina, 1997.

Mahfud, MD, Moh .., Political Law in Indonesia, Jakarta: LP3ES, 2001.

Marbun, SF, et al (ed), Dimensions of State Administration Law Thought, Jogyakarta: UII Press, 2000.

Miftah Thoha, Prima Dimensions of State Administration Science, Jakarta: PT. Grafindo Persada, 1992.

Naburi, N, et al. (2020). Watershed Governance for Food Security in the Sio River Basin: A Paradox of Kenya's Devolution System. Budapest International Research and Critics Institute-Journal (BIRCI-Journal). P. 2465-2478

NM Spelt \& JBJM ten Barge, Introduction to Licensing Law, edited by Philipus M. Hadjon, Utrecht: December 1991.

Nugraha Mursitama, Tirta et al, Licensing Service Reform and Regional Development: Success Stories of Three Cities (Purbalingga, Makassar, and Banfarbaru), Indonesian Transparency Society, Jakarta, 2010.

Rahardjo, Sacipto, Law Science, Bandung: PT. Citra Aditya Bakti, 1991.

Rianto Nugroho, Public Policy, Jakarta: Elex Media Komputindo, 2009.

Rosodjatmiko, P, Regional Government and Its Implementation, Dr. Ateng Syafrudin SH, Bandung: Tarsito, 2002.

Samodra Wibawa, Yuyun Purbokusumo, and Agus Pramusinto, Public Policy Evaluation. Jakarta: PT. Grafindo Persada, 1994. 
Setyawan Salam Dharma, Regional Autonomy in the Perspective of Environment, Values and Resources, Jakarta: Djambat, 2004.

Sigler, Jay A., Beede and Rutgers, The Legal Sources of Public Policy, Toronto: Lexington, Massaehusetts, 1977.

Soekanto, Soerjono, Introduction to Legal Research, Jakarta, UI Press, 1986.

Solichin Abdul Wahab, Policy Analysis from Formulation to Implementation of State Policy, Jakarta: Bumi Aksara, 1997.

Spelled, Mr. NM. \& JBJM Ten Berge edited Philipus M. Hadjon, Introduction to Licensing Law. Surabaya: Yuridika, 1993.

Sri Rejeki Hartono, Business Law Perspective in the Age of Technology. Inauguration Speech for the Inauguration of the Position of Professor in Commercial Law at the Diponegoro Faculty of Law, Semarang, 1995.

State Administration Agency. Preparation of Public Service Standards. Jakarta: LAN, 2003.

Sunggono, Bambang, Law and Public Policy, Jakarta: Sinar Grafika 1994.

Syafrudin, A., "Principles of Government that Deserve Handling for Regional Head Service", in the Collection of Papers of General Principles of Good Governance (AAUPB), compiler: Paulus Effendie Lotulung, Bandung: Citra Aditya Bakti, 1994.

Thomas R. Dye, Understanding Public Polic, Engelewood Chief, New Jersey Prentince-Hall Inc, 1987.

Triwulan Tutik, Titik, Principles of Constitutional Law, Jakarta: Prestasi Pustaka Publisher, 2006.

Wibowo, Eddi, Law and Public Policy, Yogyakarta: Indonesian Public Administration Reform Foundation, 2004.

William N. Dunn, Introduction to Public Policy Analysis, Second Edition, Yogyakarta: Gadjah Mada University Press, 2003.

Yunas, Didi Nazmi, Concept of State of Law, Padang: Angkasa Raya, 1992. 